\title{
Kent Parklarında Kullanıcı Tercihlerinin Değerlendirilmesi "Kyoto Japon Parkı ve Kalehan-Ecdat Parkı" Örneği
}

\author{
Sertaç Güngör ${ }^{1 *}$, Mine Çakın² \\ 1* Selçuk University, Faculty of Architecture and Design, Departmant of Landscape Architecyure, Konya, Turkey, (ORCID: 0000-0003-2703-9557), \\ sertac@selcuk.edu.tr \\ ${ }^{2}$ Selcuk University, Graduate School of Natural and Applied Sciences M.Sc. Student, Konya, Turkey, (ORCID: 0000-0001-5075-4386), mineecakn@ gmail.com
}

(1st International Conference on Applied Engineering and Natural Sciences ICAENS 2021, November 1-3, 2021)

(DOI: $10.31590 /$ ejosat.1000190)

ATIF/REFERENCE: Güngör, S., \& Çakın, M. (2021). Kent Parklarında Kullanıcı Tercihlerinin Değerlendirilmesi "Kyoto Japon Parkı ve Kalehan-Ecdat Parkı” Örneği. European Journal of Science and Technology, (28), 362-367.

$\ddot{O} \mathbf{z}$

Kent içinde bireylere dinlenme ve gezme olanağı veren mekanlar olan kent parkları, bireyleri yaşamın getirdiği stres ve bıkkınlıktan uzaklaştıran yeşil alanlar olarak tanımlanabilir. Sürekli artan nüfus, günümüzün tartışılmaz gerçeği olan küresel ısınma, kentleşme, çevre kirliliği gibi etkenler nedeniyle doğal alanlara olan ihtiyacın artmasıyla kent parkları günümüzde daha da çok tercih edilmektedir. 2021 yılına damga vuran Covid-19 pandemisi yüzünden yaşanan sokağa çıkma yasakları ve kısıtlama süreçleri nedeniyle evlerde kapalı kalan bireyler parklara özlemi fazlasıyla hissetmişlerdir. Araştırmanın amacı, adı geçen parklarda kullanıcı tercihlerinin değerlendirilmesi ve bu tercihleri etkileyen faktörlerin tespit edilmesidir. Kullanıcı tercihleri anketi, gönüllülük esasına dayanarak ve pandemi hijyen koşullarına uygun olarak 78 (26 erkek ve 52 kadın) parkları bilen ziyaretçilere uygulanmıştır. Araştırma bulgularına göre kullanıcıların parkta daha çok yaz aylarında, öğle ve akşam saatlerinde $30 \mathrm{dk}$ 'dan fazla sürede ve hafta sonu zaman geçirdikleri tespit edilmiştir. Anket katılan kullanıcıların en yüksek oranda arkadaşları veya aileleri ile parklara gittikleri saptanmıştır. Kullanıcılar daha yoğun olarak boş vakitlerinde dinlenmek ve gezmek için Kalehan-Ecdat Parkı'nı tercih etmektedir. Kyoto Japon Parkı'nda bitkisel tasarım, kent mobilyaları ve manzara güzelliği bakımından ön plana çıkmışken, Kalehan-Ecdat Parkında kolay ulaşılabilir olması, otopark sorunu olmaması, aydınlatma elemanları ve yapay göl alanından dolayı ön plana çıkmıştır. Kullanıcılar Kalehan-Ecdat Parkı'nı Kyoto Japon Parkı'na göre daha gürültülü bulmaktadırlar.

Anahtar Kelimeler: Kent parkı, Kullanıcı tercihi, Konya, Peyzaj, Kalehan-Ecdat ve Japon park1.

\section{Evaluation of User Preferences in Urban Parks "The Case of Kyoto Japan Park and Kalehan-Ecdat" Park}

\begin{abstract}
Urban parks, which are places that allow individuals to relax and visit in the city, can be defined as green spaces that remove individuals from the stresses and frustrations of life. Urban parks are more preferred today due to the ever-increasing population, the indisputable reality of today, global warming, urbanization, environmental pollution, and the need for natural areas. Due to the curfews and restriction processes experienced due to the Covid-19 pandemic that marked 2021, individuals who were confined to their homes felt a great longing for parks. The aim of the research is to evaluate user preferences in the mentioned parks and to identify the factors affecting these preferences. The user preferences survey was applied to visitors who knew 78 (26 males and 52 female) parks on a voluntary basis and in accordance with pandemic hygiene conditions. According to the research findings, users spent more than 30 minutes in the park during the summer months, lunch and evening hours, and at the weekend. The highest proportion of respondents were found to go to parks with friends or family. Users prefer Kalehan-Ecdat Park to relax and travel more intensively in their free time. While Kyoto Japon Park has come to the forefront in terms of herbal design, urban furniture and landscape beauty, kalehan-ecdat park has come to the forefront due to its easy access, lack of parking problems, lighting elements and artificial lake area. Users find Kalehan-Ecdat Park louder than Kyoto Japon Park.
\end{abstract}

Keywords: Urban park, User preferences, Konya, Landscape, Kalehan-Ecdat and Japon Park.

\footnotetext{
*Corresponding Author: sertac@ selcuk.edu.tr
} 


\section{Giriş}

Kamusal alanları barındıran ve kamusal yaşam biçimiyle kentler şekillenir. Tarih boyunca kent kavramı gelişim göstermiştir (Çınar, 2008). Kent içinde yaşayan bireyler mesai saatlerindeki azalma gelirlerdeki artma ile rekreasyona daha fazla imkân bulmakta bunuda doğa içinde gerçekleştirmektedirler. Rekreasyon gereksiniminde değerlendirilecek etkinlikler kentin imkanlarına ve sosyoekonomik gereklerine göre şekillenmektedirler. Rekreasyon imkanları fazla olan kentler yerleşim için ön plana çıkmakta ve çevresel açıdan da zengin olmaktadırlar (Özkır, 2007).

Artan nüfus kentlerin kontrolsüz, plansız büyümelerine, açık yeşil alanların azalmasına ve çevre sorunlarının artmasına neden olmuştur (Başalma, Uslu ve Körmeçli, 2017). İnsanların artan nüfus, kent içindeki karmaşa ve diğer olumsuz etkilerden kurtulmalarına katkı sağlayan kent parkların önemi giderek artmaktadir.

Kent içinde bulunan park alanları toplumun stres attığ1, mutlu olduğu ve sedanter birey olmaktan uzaklaştığı (fiziksel hareket ettiği) yerlerdir. Park alanları gerek mikroklima etkileri gerekse rekreasyon olanakları ile de ön plana çıkan yeşil alanlardır (Çetinkaya, Erman ve Uzun, 2015).

İnsan oğlunun geçirdiği dönemler boyunca kent parklarının kullanım şekilleri ve fonksiyonları değişikliğe uğramıştır. Özellikle günümüzde tecrit edilmiş yeşil alanlar olmaktan çok kullanımları çeşitli ve yeşil altyapının bir parçası olarak tanımlanmışlardır (Gürer ve Uğurlar, 2017).

Toplumda yaşayan bireylerin yoğun iş temposundan kaçıp rekreasyon imkanlarından yaralandığı yerler Kent Parkları olarak isimlendirilir (Zaloğlu, 2006).

Kent parkları özelinde bireyler stres atma ve dinlenme ihtiyaçlarını karşılamakta, yaşam kalitelerini arttırmaktadırlar. Yapisal bir alanda hapis kalan bireyler kent parkları ile nefes alabilmekte ve hareket edebilmektedirler. Parkların sahip olduğu sosyaltesisler/imkanlar, parkın lokasyonu ve ulaşılabilir olması kullanıcı memnuniyeti açısından önemlidir (Asımgil, 2012).

Kent parklarının kalite açısından yorumlanmasında farklı kriterler vardır gönüllülük esasına dayanan anket yöntemi kullanıcı memnuniyeti tespitinde kullanılan bir yöntemdir. Anketler, kent parklarının daha fonksiyonel tasarlanması ve planlanması bakımlarından değil aynı zamanda parkı kullanan yöre insanının ihtiyaçlarının belirlenmesi/karşılanması, parkların fonksiyonlarını eksiksiz olarak devam edebilmesi için de önemli bir kaynktır (Sağır ve Önal, 2018).

Bir kent parkının kullanıcı/katılımeı tarafından tercih edilmesi için ulaşım imkanlarının kolay olması, ikili ilişkilere imkân vermesi, tüm yaş grupları için aktivite içermesi, güvenliktemizlik-bakım konularında sorunlar içermemesi ve cazip tasarım kompozisyonları içermesi gerekmektedir (Özkır, 2007).

Bütüncül tasarım yaklaşımı için park kullanıcılarının istekleri ve beklentileri parkların oluşum sürecinde mutlaka göz önünde bulundurulmalıdır (Polat, 2012).

Yerel yönetimlerin gerek sosyal medya üzerinden gerekse anketlerle parkın memnuniyet durumunu ölçmeleri gerekir. Yapılacak bu araştırmalarla parkların eksiklikleri/yetersizlikleri belirlenerek önleme/düzeltme tedbirleri alınabilir (Önal ve Sağır 2018).

e-ISSN: 2148-2683
Araştırmanın amacı, kullanıcıların parklarla ilgili görüşleri alınarak anket sonuçları doğrultusunda kent sakinlerinin parkı kullanma sıklığı, hangi parkı tercih ettikleri, parklardaki mevcut donatı elemanlarının yeterliliği, parkın hangi kesime hitap ettiği ve parktaki mevcut su ögesinin, bitkisel tasarımın ve manzara güzelliğinin yeterliliğinin belirlenmesidir. Gelecekte yapılması planlanan kent parklarının tasarlanmasında ve planlanmasında bu araştırmada elde edilen verilerin yardımcı olması hedeflenmiştir. Ayrıca kullanıcı memnuniyetinin değerlendirilmesi ve farklı olarak tasarlanan parkların karşılaştırılması bunun sonucunda da kullanıcı tercihlerinin belirlenmeside hedeflenmiştir.

Kentsel açık yeşil alanlar, insanların yoğun iş hayatının stresinden, kalabalık şehirlerin gürültüsünden bir nebze de olsa uzaklaşabileceği alanlar olarak hayatımızda büyük önem taşımaktadır. $\mathrm{Bu}$ alanlar da gerek tasarımlarıyla gerek ulaşım kolaylığı gibi farklı nedenlerle tercih edilmektedir.

Beğenen kullanıcı parkı "tercih" eder. Böylelikle alanın kalitesi tespit edilebilir. Bunun en doğru yoluda uzman olmasalar bile kullanıcılarla yüzyüze/uzaktan görüşme/anket uygulamasıdır (Çakcı ve Çelem, 2008).

$\mathrm{Bu}$ yaklaşım ile kullanıcı tercihlerinin değerlendirilmesi Konya ili Selçuklu ilçesinde bulunan Kyoto Japon Parkı ve Kalehan-Ecdat Parkı temelinde ele alınmıştır.

\subsection{Kent Parkları}

Parklar; kentsel doku alanı dışında kalan farklı kullanım potansiyelleri bulunan, tasarımcılar eliyle oluşturulmuş alanların genel adıdır. $\mathrm{Bu}$ alanlarda mimari unsurlar minimum yeşil alanlar maksimum olanlar peyzaj alanlarıdır (Elinç ve Polat, 2011). Kentsel doku içindeki parklar, gerek estetik yönden gerekse sessizlikleriyle insanlara güzel duygular yaşatırlar. Farklı yaş grupları için aktivite alanları oluşturarak toplumsal yaşam gerekliliklerini sağlarlar (Işık, Kablan, Sayitoğlu, Nasin ve Odac1, 2017).

Parklar, her yaştan bireyin kullanımına açık, mekân alanı belirlenmiş, tasarımcı tarafından şekillendirilmiş açık alanlardır (Elinç ve Polat, 2011).

Kentte yaşayan bir birey olmanın yüklediği stresi atan mekanlardır. Farklı gelir seviyelerinden bireyleri bir araya getirebilirler. Mikro klima yaratma ve çevre koruma konularında önemleri her geçen gün artmaktadır (Onsekiz ve Emür, 2008).

Kentte yaşayan kullanıcıların ulaşım güçlüğü çekmeden erişebilecekleri, farklı rekreasyon faaliyetlerinde bulunabilecekleri alanlar "kent parkları"dır (Özkır, 2007).

Açık yeşil alan sistemine dahil olan sosyo-ekonomik özellikler içeren kent estetiğine katk1 veren, kent için çok olumlu katkıları olanlardır (Onsekiz ve Emür, 2008).

Kent parkları, kentte yaşayan kullanıcılara aktif faydalar sağlayan mekanlardır (Surat, 2017).

Kent parkları, bireylerin kent içinde yaşamanın getirdiği günlük koşuşturmacadan kaçabilecekleri, sosyalleşebilecekleri farklı fonksiyonları ile bireylere yaşam enerjisi veren yeşil dokuya sahip mekanlardır ve herkes tarafından bilinen temel özellikleri ile (iklim iyileştirme, hava temizleme, gürültü azaltma, vb.) önemleri ortaya çıkmaktadır (Wong ve Domroes, 2005). 
Kent parkları farklılaşan fonksiyonel kullanım alanları arasında tampon ve bağlayıcı işlev görürler. Kentin hava sirkülasyonu ihtiyacına katkıda bulunarak, mikroklima özelliği oluştururlar. Tampon özelliğine bağlı olarak, gürültüyü absorbe ederler ve içinde barındırdıkları etkinlik ve hareketlilik özelliklerine göre insanların rekreasyon gereksinimlerini karş1larlar. (Onsekiz ve Emür, 2008).

Kent parkının kullanıcılar için rahat ve huzur veren bir dinlenme ortamı olması plan karakteri ve yapılan tasarımla doğrudan ilişkilidir (Özdemir ve Polat, 2013).

Kent parkları, park türleri içerisinde sahip oldukları işlevlerine görece kent düzeyinde hizmet vermesi öngörülen parklardır. Parkın planlanmasında ise yere ve yerleşiklere özgü özelliklerin göz önünde bulundurulması, kent parklarının işlevselliğinin sağlanması açısından önemlidir. Park içinde yer alan kullanımların ve etkinliklerinin niteliğini, tasarım kuralları, kullanıcı tercihleri ve kente özgü sosyo-kültürel, iklimsel ve coğrafik özellikler belirlemektedir (Onsekiz ve Emür, 2008).

Kent parkları, her 100 kişi için 1 dekar olmak üzere, nüfusun büyüklüğüne göre, 40-400 ha arasında olmalıdır. Kent park1 etki alanı 3.200-4.000 m arasındadır. Bu parkların kentsel yerleşim birimlerine yakın ya da uzak olması önemli bir tasarım kriteri değildir. Bu alanlar en az 2-4 km, 30-60 dakikalık yürüme mesafesinde, toplu ulaşım sistemi ile doğrudan ve kolayca ulaşılabilecek mesafede 5-20 km uzaklıkta bulunmalıdır (Elinç ve Polat, 2011). Kent parkları içerisinde yürüyüş ve koşu yolları, gölet veya spor alanları, piknik alanları, spor kompleksleri, amfi tiyatro, seyir kulesi, restoran, oturma grupları, çocuk oyun aletleri bulunan ve bireylerin tek başına yada grup olarak etkinlikler düzenlenmesine firsat sağlayan, bitki materyalleri ile bir bütünlük arz eden, eğitici, kaynaştırıcı özellikleri taşıyan düzenli ve planlı olarak tasarlanmış yeşil alanlardır (Özdemir, 2012).

Bir parkın kalitesini etkileyen birçok faktör vardır. Bir parkın bütçesi, bakımı, tasarımı, düzenlemesi, parkta yer alan fiziksel durumlar ve suç aktiviteleri, kullanıcıların park alanları ile ilgili düşünceleri, park kalitesini etkiler. Parkın fiziksel durumu, algılamaların şekillenmesinde ve park içerisinde oluşabilecek suçun devam ettirilmesinde önemli bir rol oynayabilir. Bakımsız ekipmanlar ve çöplerin birikmesi, parkın potansiyel kullanıcıları üzerinde negatif fikirler oluşturarak parkın başarısını önemli derecede azaltabilir. İnsanlar, kötü ekipmanları ve çöpü, kendilerinin veya çocuklarının fiziksel güvenliğini tehdit eden durumlar olarak görebilirler (Önal, 2007).

Kalite algısı yüksek park alanları tasarlayabilmek için park tek başına değil çevresiyle beraber ele alınmalıdır. Her yaşta kullanıcı için uygun tasarım kararları verilmelidir. Kalite faktörleri doğru tasarlanmalıdır. Ancak, doğru yer seçimi, doğru planlama, doğru tasarım, doğru uygulama ve doğru bakım standartlarının yakalanması ile kent insanlarına kullanabilecekleri kalite kent parkı çevreleri oluşturulabilecektir (Onsekiz ve Emür, 2008).

\subsection{Kent Parkları ile İlgili Kalite Kriterleri}

Yaşam kalitesi ve kalite kriterleri ile ilgili faktörler, kentlere ya da kültürlere göre değişebilir ve evrensel değillerdir. Fakat hepsinin temeli sürdürülebilirliğe dayanır. Kent içerisinde önemli yere sahip olan kent parkları, sürdürülebilir özellik taşırsa o parkın kaliteli olduğuna işaret eder. Oluşan kaliteli ve sürdürülebilirlikle de kente ve insana en üst düzeyde fayda sağlanabilir (Karadeniz, 2019).

Doğru tasarlanmış bir kent parkı kullanıcılar için hayal güçlerini geliştirecek bireysel yada grup halinde dahil olabilecekleri farklı kullanımlar sağlamalı, park ulaşılabilir olmalı, güvenlik zafiyeti olmamalı, kent mobilyaları ve bitkisel peyzaj alanları bakımlı ve sağlam olmalı, her yaş grubuna ve fiziksel yapıya sahip bireye parkı kullanma olanağ1 vermelidir (Yücel ve Yıldızcı, 2006). Kent parkı kalite kriterleri aşağıdaki gibidir;

Aktivite ve kullanımlar: Park alanı her yaş grubuna hitap etmeli ve onların ihtiyacına uygun aktiviteleri barındırmalıdır (Özkır, 2007). Pek çok farklı aktiviteyi bünyesinde taşımalıdır. Farklı yaşlarda kullanıcılar alana farklı anlamlar yükler ve farklı beklentiler içerisinde olurlar bu yüzden parklar her yaş grubuna hitap etmelidir (Yücel ve Yıldızc1, 2006).

Ulaşılabilirlik: Park alanına kent içindeki farklı ulaşım vasıtalarıyla gidilebilmelidir, ayrıca park içinde oryantasyon rahat olmalıdır. Park alanlarına yaya, özel oto, bisiklet veya otobüs gibi değişik ulaşım araçlarıyla ulaşımın sağlanması gerekir. Oryantasyon için park planının karmaşık olmaması gerekir. Döşeme farklılıkları ve bitkisel kompozisyonda değişimler gibi unsurlarla bu yaratılabilir (Yücel ve Yıldızcı, 2006).

Konfor ve İmaj: Güvenlik/bakım/sıhhi tesisler gibi kullanımlar park konforunun/imajının oluşumu için önemlidir (Yücel ve Yıldızcı, 2006). Kullanıcıların zarar görmesine olanak vermeyecek, güvenli/temiz bir ortamda aktivitelere imkân sağlamalıdır (Konakoğlu ve Bekar, 2021).

Kent parklarında yaşayan faunanın ve yaşam ortamı oluşturan floranın zarar görmemesi gerekir (Özkır, 2007). Parkta güvenlik açığı oluşmaması için aktivitelerce zengin hale getirilmeli ıssız bırakılmamamalıdır (Yücel ve Yıldızcı, 2006).

Bakım ve temizlik, parkın kullanıcılar tarafından tercih edilebilmesindeki en önemli kalite kriterlerinden bir tanesidir. Kent parkı içindek mobilyaların bakımı/yenilenmesi, atıkların alandan uzaklaştırılması ve yeşil alanların bakımlarının yapılması önemlidir. Park alanına göre uygun sayıda personel bulundurulmalıdır (Karadeniz, 2019).

Sosyallik: Toplumlar için olmazsa olmaz bir bileşendir. Aynı yada farklı yaş grupları bir araya gelerek yeni ilişkiler/bağlantılar kurarlar ve yabancılarla rahatça tanışırlar. $\mathrm{Bu}$ sayede mekâna karşı aidiyet hisleri artar (Yücel ve Yıldızcı, 2006).

\section{Materyal ve Metot}

\subsection{Materyal}

Çalışmada, kent parklarında kullanıcı tercihlerinin belirlenmesi için Konya ili Selçuklu bölgesinde Kalehan-Ecdat Parkı ve Kyoto Japon Parkı ana materyal olarak seçilmiş ve bu parklar özelinde yürütülmüştür.

Selçuklu ilçesinde bu park alanlarının seçilme nedenleri, yapısal ve bitkisel yoğunluk olarak geniş alan kaplamaları, yerel halk tarafindan kent içinde rekreasyon amaçlı yoğun olarak tercih ediliyor olmaları ve Konya ilinde farklı sosyokültürel yapıdaki bireylere hitap ediyor olmasıdır. 


\subsection{Metot}

Araştırmada gönüllülük esasına göre anket yapılmıştır. Anket soruları Google formlar ile hazırlanmış olup kişisel bilgiler ve kullanıcı tercihleri ile ilgili sorular olmak üzere 2 bölümden oluşmuştur. Covid-19 pandemi şartlar nedeniyle anketler sosyal medya üzerinden yapılmıştır. Parkı daha önce ziyaret etmiş rastgele 78 kişiye anket soruları sorulmuştur. Anket linki Facebook ve İnstangramda Konya, Japon Parkı ve KalehanEcdat Parkı sayfalarında ve yazarların kişisel hesaplarında konu hakkında bilgi verilerek paylaşılmıştır. Anket yapılacak toplam kişi sayısı Güngör 2019'a göre seçilmiş ve uygulanmıştır.

\subsubsection{Kyoto Japon Park}

Konya Büyükşehir Belediyesi tarafından 2010 y1lında hizmete sunulan ve 36 bin metrekarelik alanıyla Türkiye'nin en büyük Japon Bahçesi olan Konya Japon Parkı, Konya ile Kyoto arasında kardeşlik ilişkilerinin geliştirilmesi amacıyla yaptırılmıştır. Ortada bir göl ve çevresinde yürüme yolu bulunmaktadır. Gölde de Japon balıkları mevcuttur ve göl üzerinden geçen taş ve ahşap köprülerden bu balıkları izleyebilme imkanı vardır. Japon mimarisine uygun olarak yapılan parkta göletler, peyzaj düzenlemeleri, taş ve ahşap köprüler, Japon bitkileri, bambu su oyunları dikkat çekerken; Japon kültürüne uygun ikramların yapıldığı kafeterya da büyük ilgi görmektedir (Aylan ve Şalvarc1, 2018).

\subsubsection{Kalehan-Ecdat Parkı}

Kalehan-Ecdat bahçesi Konya ili Selçuklu ilçesi Yazır Mahallesi'nde yer alan bir kent parkıdır. Konya Büyükşehir Belediyesi tarafından Otogar ve Yeni Büyükşehir Stadyumu bölgesine kazandırılan 110 bin metrekarelik bir parktır.

Parkın içinde 12 bin 500 metrekare gölet ile etrafında kale burçları ve surlar, Osmanlı Sokağı, Boğaz Yalısı, Hasbahçe, Selçuklu Hanı Konya Mutfağı, kamelyalar ve sosyal donatılar bulunmaktadır. Selçuklu hanının restoran olarak hizmet vereceği, kamelyalar ve sosyal donatıların da yer aldığı parkın göletinde ise kayıklarla gezinti yapılabilmektedir. Zirh ve kalkanıyla Osmanlı askerini canlandıran iki görevlinin nöbet beklediği kapıdan giren ziyaretçilere, parkta Yeniçeriler ile atlı Selçuklu askerleri eşlik etmektedir (Anonim 2019)

Tablo 1. Kalehan-Ecdat Parkı ve Kyoto Japon Parkı kullanıcı görüşleri

\begin{tabular}{|c|c|c|c|c|c|c|c|c|c|c|}
\hline & \multicolumn{2}{|c|}{$\begin{array}{l}\text { Kesinlikle Evet } \\
\text { Kişi sayısı (n) }\end{array}$} & \multicolumn{2}{|c|}{$\begin{array}{l}\text { Evet } \\
\text { Kişi sayısı (n) }\end{array}$} & \multicolumn{2}{|c|}{$\begin{array}{l}\text { Kararsızım } \\
\text { Kişi sayısı (n) }\end{array}$} & \multicolumn{2}{|c|}{$\begin{array}{l}\text { Hayır } \\
\text { Kişi sayısı (n) }\end{array}$} & \multicolumn{2}{|c|}{$\begin{array}{l}\text { Kesinlikle Hayır } \\
\text { Kişi sayısı (n) }\end{array}$} \\
\hline & $\begin{array}{l}\text { Kalehan } \\
\text { Ecdat } \\
\text { Parkı }\end{array}$ & $\begin{array}{l}\text { Kyoto } \\
\text { Japon } \\
\text { Parkı }\end{array}$ & $\begin{array}{l}\text { Kalehan } \\
\text { Ecdat } \\
\text { Parkı }\end{array}$ & $\begin{array}{l}\text { Kyoto } \\
\text { Japon } \\
\text { Parkı }\end{array}$ & $\begin{array}{l}\text { Kalehan } \\
\text { Ecdat } \\
\text { Parkı }\end{array}$ & $\begin{array}{l}\text { Kyoto } \\
\text { Japon } \\
\text { Parkı }\end{array}$ & $\begin{array}{l}\text { Kalehan } \\
\text { Ecdat } \\
\text { Parkı }\end{array}$ & $\begin{array}{l}\text { Kyoto } \\
\text { Japon } \\
\text { Parkı }\end{array}$ & $\begin{array}{l}\text { Kalehan } \\
\text { Ecdat } \\
\text { Parkı }\end{array}$ & $\begin{array}{l}\text { Kyoto } \\
\text { Japon } \\
\text { Parkı }\end{array}$ \\
\hline Bitkisel tasarımını yeterli mi? & 21 & 31 & 17 & 36 & 19 & 5 & 15 & 6 & 7 & 1 \\
\hline Çöp kutularını yeterli mi? & 18 & 15 & 31 & 44 & 19 & 15 & 9 & 7 & 2 & 0 \\
\hline $\begin{array}{l}\text { Oturma elemanlarını (Bank, kamelya vb.) } \\
\text { yeterli mi? }\end{array}$ & 21 & 13 & 20 & 31 & 16 & 19 & 17 & 14 & 5 & 1 \\
\hline Aydınlatma elemanlarını yeterli mi? & 26 & 18 & 33 & 37 & 15 & 16 & 3 & 8 & 1 & 0 \\
\hline Otopark sayısını yeterli mi? & 17 & 9 & 21 & 18 & 24 & 17 & 12 & 22 & 4 & 12 \\
\hline $\begin{array}{l}\text { Parkta kendinizi güvende hissediyor } \\
\text { musunuz? }\end{array}$ & 27 & 22 & 36 & 41 & 13 & 11 & 1 & 4 & 3 & 1 \\
\hline Manzara güzelliğini yeterli mi? & 25 & 23 & 29 & 38 & 11 & 10 & 9 & 6 & 5 & 1 \\
\hline Parka kolay ulaşabiliyor musunuz? & 33 & 27 & 32 & 35 & 9 & 9 & 5 & 7 & 0 & 1 \\
\hline Bakım çalışmalarını yeterli mi? & 28 & 21 & 30 & 34 & 14 & 14 & 4 & 8 & 2 & 2 \\
\hline Parkın büyüklüğünü yeterli mi? & 39 & 20 & 32 & 27 & 6 & 15 & 1 & 11 & 0 & 6 \\
\hline Su öğesini yeterli mi? & 34 & 22 & 28 & 31 & 13 & 15 & 4 & 9 & 3 & 3 \\
\hline $\begin{array}{l}\text { Gürültüü seviyesinin fazla olduğunu } \\
\text { düşünüyor musunuz? }\end{array}$ & 23 & 16 & 19 & 17 & 13 & 21 & 20 & 23 & 7 & 3 \\
\hline
\end{tabular}

\section{Araştırma Sonuçları ve Tartışma}

\subsection{Katılımcıların Kişisel Bilgileri}

Ankete katılan park kullanıcılarının \% 33'ü erkek (26 kişi), \% 67'si kadındır (52 kişi). Katılımcıların, \%5'i 18 yaş altı (4 kişi), \%31 'i 18-25 yaş arası (24 kişi), \%42'si 26-35 yaş arası (33 kişi), \%17'si 36-45 yaş arası (13 kişi), \%4'ü 46-55 yaş arası (3 kişi), \%1'i 65 yaş üstü (1 kişi) yaş aralığındadır. 56-65 yaş aralığında katılım olmamıştır. Eğitimleri incelendiğinde katılımcıların \%1'i okur-yazar (1 kişi), \%4'ü ilköğretim (3 kişi), \%8'i ortaokul (6 kişi), \%14'ü önlisans (11 kişi), \%46'sı lisans (36 kişi) ve \%27'si lisansüstü (21 kişi) olduğu görülmektedir Çalışmada katılımcıların, 17'si devlet memuru (\%22), 5'i işçi (\%6), 3'ü esnaf (\%4), 15'i ev hanımı (\%19), 24 ‘ü öğrenci (\%31) ve 14 'ü diğer (\%18) seçeneğini işaretlemiştir.

\subsection{Katılımcı Tercihleri}

Katılımcılara 'Boş vakitlerinizde dinlenmek ve gezmek için Kyoto Japon Parkı ve Kalehan Ecdat Parklarından en çok hangisini tercih edersiniz?' diye sorulduğunda \%38'i Kyoto Japon Parkı (31 kişi), \%56'sı Kalehan Ecdat Parkı (44 kişi) ve \%4'ü diğer (3kişi) seçeneğini işaretlemiştir. Ankete katılanlara parkları (Kyoto Japon Parkı, Kalehan Ecdat Parkı) hangi saatlerde kullandıkları sorulduğunda; \%9'u sabah (7 kişi), \%45'i öğle (35 kişi), \%46'sı akşam (36 kişi) cevabını vermiştir. Katılımc1lara parkta (Kyoto Japon Park1, Kalehan Ecdat Park1) geçirdikleri zaman sorulduğunda; \%1'i $15 \mathrm{dk}$ (1 kişi), \%6's1 30 dk'dan az (5 kişi), \%45'i 30-60 dk (35 kişi), \%47'si 1 saatten fazla (37 kişi) cevabını vermiştir. Parka en sık gelinen mevsim sorulduğunda; katılımcıların 23'ü ilkbahar (\%29), 51'i yaz (\%65), 2'si sonbahar (\%3) ve 2'si kış (\%3) cevabını vermiştir. Katılımcılara parka en sık geldikleri gün sorulduğunda; 24'ü 
haftaiçi (\%31), 54’ü haftasonu (\%69) cevabını vermiştir. Ankete katılanlara parkta kiminle/kimlerle vakit geçirdiği sorulduğunda; 3'ü tek başına (\%4), 38'i arkadaşlarla (\%49), 33'ü aile ile (\%42) ve 4'ü diğer (\%5) seçeneğini işaretlemiştir. Katılımcılara 'Kyoto Japon Parkı aşağıdaki kullanıcılardan hangisine hitap ediyor?' diye sorulduğunda; \%6'sı yaşlılar (5 kişi), \%3'ü çocuklar (2 kişi), \%22'si gençler (17 kişi) ve \%69’u hepsi (54 kişi) seçeneğini işaretlemiştir. Engelliler seçeneğine işaretleme yapılmamıştır. Ankete katılan kullanıcılara 'Kalehan Ecdat Parkı aşağıdaki kullanıcılardan hangisine hitap ediyor?' diye sorulduğunda; \%5'i yaşlılar (4 kişi), \%3'ü çocuklar (2 kişi), \%6'sı gençler (5 kişi) ve \%86'u hepsi (67 kişi) seçeneğini işaretlemiştir. Engelliler seçeneğine işaretleme yapılmamıştır. Anketin son kısmında kullanıcılara likert tipi sorular sorularak, alandaki bitkisel tasarım, kent mobilyaları, bakım çalışmaları vb

\section{Sonuç}

Sosyal medya üzerinden Google anket uygulaması yardımıla 26 erkek ve 52 kadın olmak üzere parkları kullanmış olana toplam 78 kişiye ulaşılmıştır. Anket sonucunda 26-35 yaş arası kullanıcı katılım sayısının daha yüksek olduğu ve 65 yaş üstü kullanıcıların parklardan daha az yararlandığı belirlenmiştir. Ankete katılan kullanıcıların büyük çoğunluğunun önlisans ve üstü eğitim seviyesine sahip olduğu ve kullanıcıların büyük çoğunluğunun öğrenci olduğu görülmektedir. Kullanıcıların boş vakitlerinde dinlemek ve gezmek için daha çok Kalehan-Ecdat Parkını tercih ettikleri belirlenmiştir. Parkları çoğunlukla öğle ve akşam saatlerinde ziyaret ettikleri ve $30 \mathrm{dk}$ 'dan fazla zaman geçirdikleri anlaşılmaktadır. Bu yüzden parklarda öğle ve akşam saatlerinde güvenliğin arttırılması ve aydınlatmaların yeterliliği parkın tercih edilmesinde önemli rol oynamaktadır. Araştırmada en sık yaz aylarında, haftasonu parka gitmeyi tercih ettikleri ve büyük çoğunluğun aile ve arkadaşlarıyla zaman geçirdikleri saptanmıştır. İnsanlar haftaiçi okul ve iş yorgunluğunu stresini atmak için parkları tercih etmektedir. Kyoto Japon Parkı ve Kalehan-Ecdat Parkı'nın çoğunlukla herkese hitap ettiği sonucuna ulaşıılmıştır. Bitkisel tasarım olarak Kyoto Japon Parkı, Kalehan-Ecdat Parkı'ndan daha yeterli bulunmuştur. Fakat bitkisel tasarımın yeterli olması Kyoto Japon Parkını daha çok tercih edilen park yapmamıştır bunun sebebinin Kalehan-Ecdat Parkının daha kolay ulaşılabilir olduğu söylenebilir. Araştırma sonucunda çöp kutuları ve oturma elemanları Kyoto Japon Parkında yeterli olduğu anlaşılırken aydınlatma elemanları ve otopark sayısı Kalehan-Ecdat Parkında yeterli bulunmuştur. Kyoto Japon Parkı hem kolay ulaşılabilir olmaması hem de otopark sayısının yetersiz bulunması nedeniyle daha az tercih edilmektedir. Her iki parkta da kullanıcılar kendilerini güvende hissetmektedir bunun nedeni her iki parkta da güvenlik bulunması ve etrafının duvarlarla çevrili olması kullanıcıların kendilerini güvende hissetmelerine neden olmaktadır. Kyoto Japon Park1 manzara güzelliği bakımından daha yeterli bulunmuştur. Bitkisel tasarımın yeterli olması ve su ögesi ile japon mimarisine uygun bitkilerin birlikte bi uyum içerisinde olması neden olmaktadır. Kalehan-Ecdat Parkı konut alanlarına ve alışveriş merkezine yakınlık dolayısıyla gürültü seviyesinin fazla bulunduğu anlaşılmaktadır. Kyoto Japon Parkına göre Kalehan-Ecdat Parkı'nın bakım çalışmalarının yeterli olduğu anket sonuçlarına göre anlaşılmaktadır. Bakım çalışmalarının yeterliliği de parkın tercih edilme oranını etkilemektedir. Parkın büyüklüğü ve su ögesinin yeterliliği bakımından Kalehan-Ecdat Parkı, Kyoto Japon Parkına göre daha yeterli bulunmuştur. konularda Kalehan Ecdat Parkı ve Kyoto Japon Parkı'nın yeterliliği hakkında fikirleri alınmıştır. Bitkisel tasarım olarak Kyoto Japon Parkı yeterli bulunurken (\%67), parkın büyüklügü açısından Kalehan Ecdat Parkı yeterli bulunmuştur (\%71). Kullanıcılar çöp kutuları (\%59) ve oturma elemanlarını (\%44) Kyoto Japon Parkında yeterli bulurken, aydınlatma elemanları (\%59) ve otopark (\%38) bakımından Kalehan Ecdat Parkını yeterli bulmaktadır. Kyoto Japon Parkı ve Kalehan Ecdat Parkı'nda kendini güvende hisseden kullanıcıların sayısı eşittir (\%63). Kalehan Ecdat Parkı, Kyoto Japon Parkına göre daha kolay ulaşılabilir bulunmuştur (\%65). Bakım çalışmaları (\%58) ve su ögesi (\%62) Kalehan Ecdat Parkında yeterli bulunurken, manzara güzelliği bakımından Kyoto Japon Parkı daha yeterli bulunmuştur (\%61). Kalehan Ecdat Park1 Kyoto Japon Parkına göre daha gürültülü olduğu anlaşılmaktadır (\%42

Konya'nın Selçuklu ilçesinde bulunan Kyoto Japon Parkı ve Kalehan-Ecdat Parkı örneğinde yapılan araştırmanın sonuçlarına bakılarak manzara güzelliği ve bitkisel tasarımın yeterli olduğu parklar; kolay ulaşılabilen, bakım çalışmaları düzenli yapılan, aydınlatma elemanları, otoparkların ve su ögesinin yeterli olduğu parklara göre daha az tercih edildiği söylenebilir.

\section{Teșekkür}

Bu makale 1. Uluslararası Uygulamalı Mühendislik ve Doğa Bilimleri Konferansında (1st. International Conference on Applied Engineering and Natural Sciences ICAENS 2021) sözlü bildiri olarak sunulmuş ve özeti basılmıştır.

\section{Kaynakça}

Anonim, (2019). [online], http://www.konyagezirehberi.net/konya-kalehan-ecdatbahcesi-parki-adres-resimler-ve-genel-bilgiler, Tarihi: 02.05.2021].

Asımgil B., (2012). Kent Parklarının Sürdürülebilir Planlaması Balıkesir Örneği, Megaron, 7(1), 1-14.

Aylan F.K., Şalvarcı S., (2018). Kent Turizmi Açısından Rekreasyon Alanlarının Önemi: Konya Temalı Parklar Örneği, Uluslararası Turizm ve Sosyal Araştırmalar Dergisi, Say1:3 49-62.

Başalma D. E., Uslu A. ve Körmeçli P.Ş., (2017). Kent Park1 Kalite Göstergelerinin Değerlendirilmesi Kapsamında Bir Deneme: Ankara/100. Y1l Birlik Parkı Örneği, Uluslararası Peyzaj Mimarlığı Araştırmaları Dergisi, 1 (1), 8-13.

Çakcı I., Çelem H., (2009) Kent Parklarında Görsel Peyzaj Algısının Değerlendirilmesi, Ankara Üniversitesi Ziraat Fakültesi Tarım Bilimleri Dergisi, 15(1), 88-95.

Çetinkaya G., Erman A., Uzun M.S., (2015). Rekreasyonel amaçlı park kullanıcılarının memnuniyet ve memnuniyetsizlik faktörlerinin belirlenmesi, International Journal of Human Sciences, 12(1), 851-869.

Çınar İ., (2008). Kent Parklarının Rekreasyonel Yönden Yeterliği Üzerine Fethiye-Muğla Kent Parkları Örneğinde Bir Araştırma, ADÜ Ziraat Fakültesi Dergisi, 5(2), 33-38.

Elinç H., Polat A.T., (2011). Görsel Kalite Değerlendirmesi Yöntemi İle Antalyaili Alanya İlçesindeki Abdurrahman Alaettinoğlu Ve Alanya Belediye Başkanları Kent Parklarının İrdelenmesi, Selçuk Üniversitesi Fen Bilimleri Enstitüsü Yüksek Lisans Tezi, 129.

Güngör, S. (2019). Yaşlı Bireyler Açısından Peyzaj Tasarımının Konya Japon Parkı Örneğinde İncelenmesi. Yüzüncü Yıl 
Üniversitesi Tarım Bilimleri Dergisi, Volume: 29 Number: Special Issue, 54-62. DOI: 10.29133/yyutbd.475409

Gürer N., Uğurlar A., (2017). Kent Parklarında Kullanıcı Memnuniyeti: Ankara Kuğulu Park Örneği, Megaron, 12(3), 443-459.

Işık B. Ö., Kablan Y., Sayitoğlu Ç., Nasin D., Odacı G.S., (2017). Kullanıcıların Kent Donatılarının Kullanılırlığına Etkisi, Akademik Sosyal Araştırmalar Dergisi, 151-164.

Karadeniz Z., (2019). Peyzaj Tasarım Kriterleri Açısından Samsun Kent Parklarının İncelenmesi, Yüksek Lisans Tezi, Ordu Üniversitesi Fen Bilimleri Enstitüsü, Peyzaj Mimarlı̆̆ Anabilim Dalı.

Konakoğlu Z. N., Bekar G. İ., (2021). Kent Parkları ile Kent Kimliği İlişkisi: Trabzon Örneği, Akademik Sosyal Araştırmalar Dergisi, s. 211-223.

Onsekiz D., Emür S.H., (2008). Kent Parklarında Kullanıcı Tercihleri ve Değerlendirme Ölçütlerinin Belirlenmesi, Sosyal Bilimler Enstitüsü Dergisi Say :24 69-104.

Önal S., (2007). Kent Parklarda Kullanılan Donatıların Standartlara Uygunluğunun Belirlenmesi: Ankara Örneği, Antropoloji, (38), 54-64.

Önal S., Sağır M., (2018). Ankara Kent Parklarının Kullanımının Belirlenmesi, Ankara Araştırmaları Dergisi, 6(1), 77-90.

Özdemir B., Polat A.T., (2013). The Evaluation of User Preferences: the Case of Urban Parks in Konya, The Journal of MacroTrends in Energy and Sustainability, 48-58.

Özdemir, B., (2012). Kent Parklarının Kentsel Yaşam Kalitesine Katkıları, Yüksek Lisans Semineri, Selçuk Üniversitesi Fen Bilimleri Enstitüsü, Peyzaj Mimarlığı Anabilim Dalı Konya.

Özkır A., (2007) Kent Parkları Yönetim Modelinin Geliştirilmesi, Doktora Tezi, Ankara Üniversitesi Fen Bilimleri Enstitüsü, Ankara, 11-29.

Surat H., (2017). Kent Parklarının Görsel Peyzaj Algısının Peyzaj Mimarlı̆ğ Öğrencileri Tarafından Değerlendirilmesi, Bartın Orman Fakultesi Dergisi, 70-80.

Wong K. K., Domroes M., (2005). The Visual Quality Of Urban Park Scenes Of Kowloon Park, Hong Kong: Likeability, Affective Appraisal, And Cross-Cultural Perspectives, Environment And Planning B: Planning And Design, 32(4), 617-632.

Yücel G.F., Yıldızcı A.C., (2006). Kent Parkları İle İlgili Kalite Kriterlerinin Oluşturulması, İTÜDERGISIİa, 5(2).

Zaloğlu A., (2006). Ankara Kent Parklarında Suyun Gösteri Elemanı Olarak İrdelenmesi, Ankara Üniversitesi Fen Bilimleri Enstitüsü, Peyzaj Mimarlığı Anabilim Dalı Yüksek Lisans Tezi. Ankara. 